\title{
EFFECT OF USING DIFFERENT LEVELS AND SOURCES OF FATS AND ROUGHAGES ON PRODUCTIVE CHECKED PERFORMANCE, RUMEN FERMENTATION AND SOME BLOOD PARAMETERS IN RUMINANT. \\ 2: THE INFLUENCE OF PROTECTED FAT AS A DIETARY SUPPLEMENTATION ON PRODUCTIVE PERFORMANCE OFOSSIMLAMBS.
}

Shakweer, I.M.E; A.A.M. EI-Mekass; K.E.I. Etman and T.I. El-Monayer.

Animal Production Research Institute, Agricultural Research Center, Ministry of Agricuture, Giza, Egypt.

\begin{abstract}
This study was conducted to investigate the effect of feeding different levels of protected fat on the digestion coefficients, nutritive value, ruminal and some blood parameters, and productive performance of Ossimi lambs. Three levels of protected fat $(0,4$ and $8 \%)$ were used to cover $0,10.80$ and $19.98 \%$ of the total energy of the formulated rations, respectively. Twenty four Ossimi lambs averaging initial live body weight of $32.39 \pm 0.63 \mathrm{~kg}$ and aging 5-6 months were chosen and divided into three similar groups (eight animals each). Animals in all groups were fed on isonutrigenous complete mixed ration for 112 days as an experimental period.. Results indicated that animals fed rations containing protected fat increased $(P<0.05)$ digestibility coefficients of DM, OM, CP, EE and NFE than those fed control ration. High level of protected fat $(8 \%)$ improved $(P<0.05)$ the nutritive value as TDN and DCP than those fed control ration, being $61.35,66.84$ and $72.07 \%$ for TDN and 8.87 , 9.32 and $9.96 \%$ for DCP in lambs fed 0,4 and $8 \%$ protected fat diets, respectively. Concentration of ammonia- $N$ and total VFA's increased $(P<0.05)$ by increasing protected fat level at different post-feeding times. The differences in concentration of albumin, globulin and cholesterol in blood plasma was not affected significantly by the experimental rations, but concentration of total proteins, triglycerides and total lipids increased $(\mathrm{P}<0.05)$ in lambs fed $8 \%$ protected fat as compared to control lambs. Average daily gain was 241, 262, and $282 \mathrm{~g} /$ head for animals fed 0,4 and $8 \%$ protected fat rations $(\mathrm{P}<0.05)$. Also, Animals fed $8 \%$ protected fat ration showed the best feed efficiency expressed as $\mathrm{kg} \mathrm{DM} / \mathrm{kg}$ gain (4.550), while those fed $4 \%$ protected fat ration recorded the best efficiency as TDN or DCP (3.172 and 0.443$)$, respectively. Animals fed $8 \%$ protected fat showed the highest revenue and economical efficiency, being 5.059 and 2.498 , respectively.
\end{abstract}

Keywords: Ossimi lambs, protected fat, feed efficiency, digestibility, ruminal and blood parameters.

\section{INTRODUCTION}

The energy density of a ruminant ration can be enhanced by incorporating fermentable carbohydrates such as cereal grains or fats. However there is limitation to the use of high levels of cereal grains in the ration as it reduces rumen $\mathrm{pH}$ which can cause rumen acidosis. Forage intake and/or utilization by sheep (Devendra and Lewis, 1974; Sutton et al., 1983) and cattle (Jenkins and Jenny, 1989) was decreased by addition of 
dietary fat. However, calcium could improve fiber digestibility in the fat added diets by forming insoluble soaps, which remove the fatty acids from rumen fluid, so that they were no longer available to rumen bacteria (Palmquist and Jenkins, 1980).

An alternative method to avoid the inhibitory effect of added fat on the ruminal ecosystem is the use of ruminally protected fat. When calcium salts of fatty acids were added at $0,2,4$, or $6 \%$ to finishing beef diets, neutral detergent fiber (NDF) digestibility linearly increased and acid detergent fiber (ADF) digestibility tended to increase with increasing dietary calcium salts of fatty acids (Nigdi et al., 1990). However, Sutton et al. (1983) reported that protected linseed oil and protected coconut oil caused a large depression in NDF digestion in the sheep rumen. It was indicated that the apparent inconsistency might be due to the extent of protection, which resulted in a release of oil or fatty acids in the rumen fluid at a slow rate, which allowed hydrogenation of fatty acids to occur, and thus impaired microbial activity. Doreau and Chilliard (1997) noted that inclusion of fats in the diet might be appropriate for ruminants with high energy requirements. In addition, fats prevent ruminal acidosis, facilitate absorption of lipsoluble nutrients and make it possible to modify meat or milk fat composition according to consumer demand. Dietary fat may modify the ruminal microbial population, which is responsible for cellulose digestion, but has few effects on other propionateproducing organisms (Doreau and Chilliard, 1997).

Inclusion of fat in ruminant diets improves energy efficiency due to the lower ruminal production of methane and direct use of long-chain fatty acids in the metabolic pathways of fat synthesis, without the need for acetate and glucose (Doreau and Chilliard, 1997). In this respect, Zinn (1989) observed a linear increase in average daily gain, and linear decrease in feed intake and empty body gain, when fat was added to finishing diets for steers.

Aim of this work was to study the effect of rations containing different levels of protected fat and roughages on digestibility, feeding value, ruminal fermentation, blood parameters, growth performance and economic efficiency of Ossimi lambs.

\section{MATERIALS AND METHODS}

Twenty four Ossimi lambs were used in this work to study the effect of dietary inclusion of dried protected fat (PF)at levels of 0, 4 and $8 \%$ instead of yellow corn as source of energy. The overall initial live body weight of lambs was $32.39 \pm 0.63 \mathrm{~kg}$ At age of $5-6$ months. lambs were divided into three similar groups (eight animals each). All groups were fed on a complete mixed ration as shown in Table (1). 
Table (1): Ingredients composition of different experimental diets.

\begin{tabular}{|l|c|c|c|}
\hline \multirow{2}{*}{ Ingredient (\%) } & \multicolumn{3}{|c|}{ Experimental ration } \\
\cline { 2 - 4 } & $\mathbf{A}$ (0\% PF) & $\mathbf{B ~ ( 4 \% ~ P F ) ~}$ & $\mathbf{C ~ ( 8 \% ~ P F ) ~}$ \\
\hline Yellow corn & 36 & 32 & 28 \\
\hline Wheat bran & 23 & 23 & 23 \\
\hline Soya bean meal & 15 & 15 & 15 \\
\hline Wheat straw & 7 & 7 & 7 \\
\hline Berseem straw & 5 & 5 & 5 \\
\hline Berseem hay & 5 & 5 & 5 \\
\hline Undicorticated cotton seed cake & 5 & 5 & 5 \\
\hline Protected fat & 0 & 4 & 8 \\
\hline Lime stone & 2.5 & 2.4 & 2.3 \\
\hline Salt & 1 & 1 & 1 \\
\hline Mineral and vitamin mixture & 0.5 & 0.5 & 0.5 \\
\hline Urea & 0 & 0.10 & 0.20 \\
\hline
\end{tabular}

Protected fat was used as a source of energy and incorporated with 0,4 and $8 \%$ to cover $0,10.80$ and $19.98 \%$ of energy (TDN) for rations A, B and $\mathrm{C}$, respectively. All rations were iso-nitrogenous. Nutrient requirements for experimental lambs were adjusted fortnightly to cope with body weight changes according to NRC (1985). The complete mixed rations were offered twice daily at 8.0 a.m. and 4.0 p.m. The lambs were weighed biweekly and water was offered freely. The feeding trial lasted for 112 days. Live body weight changes and feed intake were recorded at two weeks interval. At the end of the experimental period, three lambs from each group were chosen randomly to determine the nutrients digestibility of the experimental three rations. Chemical composition of the feed and feces samples were analyzed according to A.O.A.C. (2000) procedures. Rumen liquor samples were strained in four folds of cheese cloth and $\mathrm{pH}$ value was determined immediately using a digital $\mathrm{pH}$ meter. Ammonia- $\mathrm{N}$ was determined according to the modified Semi-micro Kijeldehl digestion method (A.O.A.C., 2000). Concentration of total volatile fatty acids (TVFA's) was determined according to Eadie et al. (1967). At the end of the collection period in each digestion trial, blood samples were taken from the jugular vein and allowed to flow into acid washed heparinzied tubes, and centrifuged at 3000 r.p.m. for 15 min to separate plasma, which was stored at $-20^{\circ} \mathrm{C}$ until analysis. Concentration of total protein and albumin was determined according to Weichselboum (1946) and Drupt (1974), respectively. Concentration of triglycerides, total lipids and cholesterol was determined according to Scheletter and Nussel (1975)and Stein (1986), respectively. Activity of transaminases (AST and ALT) was determined according to Reitman and Frankel (1957). The obtained data were statistically analyzed by general linear, model using ANOVA procedures of SAS (1985). The significant differences among treatments were tested using Duncans multiple range test (Duncan, 1955).

\section{RESULTS AND DISCUSSION}

Data presented in table (2) showed the chemical composition of the different experimental rations. It could be noticed that the content of $\mathrm{CP}$ 
recorded $15.97,15.85$ and $15.77 \%$ for rations $A, B$ and $C$, respectively. The three different experimental rations were nearly iso-nitrogenous, while the corresponding contents of EE were $2.70,6.92$ and $9.38 \%$, respectively.

Table (2): Chemical composition of the experimental rations( on DM basis \%).

\begin{tabular}{|l|c|c|c|}
\hline \multirow{2}{*}{ Item } & \multicolumn{3}{|c|}{ Experimental ration } \\
\cline { 2 - 4 } & $\mathbf{A}$ & $\mathbf{B}$ & $\mathbf{C}$ \\
\hline DM & 88.70 & 88.79 & 88.84 \\
\hline OM & 92.29 & 92.40 & 92.52 \\
\hline CP & 15.97 & 15.85 & 15.77 \\
\hline EE & 2.70 & 6.92 & 9.38 \\
\hline CF & 11.89 & 11.78 & 11.65 \\
\hline NFE & 61.73 & 57.85 & 55.72 \\
\hline Ash & 7.71 & 7.60 & 7.48 \\
\hline
\end{tabular}

Also, it could be noticed that the CF contents were slightly lower by increasing protected fat level. The CF contents recorded 11.89, 11.78 and $11.65 \%$ in rations $A, B$ and $C$, respectively. The same trend was shown for NFE contents, showing a decrease by increasing protected fat level (61.73, 57.85 and $55.72 \%$ for $A, B$ and $C$ rations, respectively). However, contents of DM and OM were almost equal for all rations (Table 2).

Nutrients digestibility and nutritive values of the experimental rations:

Results indicated that inclusion of protected fat to experimental rations tended to increase $(P<0.05)$ digestibility coefficient of $D M, O M, C P, E E$ and NFE, while CF digestibility coefficient appeared to decrease by increasing protected fat level. It could be noticed that the ration containing $8 \%$ protected fat (ration $\mathrm{C}$ ) recorded higher digestibility coefficient nutrients than that containing 4\% (ration B), but the differences were not significant (Table 3). At the same time, nutritive values of the experimental rations expressed as TDN, DE, ME and DCP contents are sown in Table (3).

Table (3): Digestion coefficients and nutritive values of different experimental Rations.

\begin{tabular}{|l|c|c|c|}
\hline \multirow{2}{*}{ tem } & \multicolumn{3}{|c|}{ Experimental ration } \\
\cline { 2 - 4 } & A & B & C \\
\hline Digestion coefficients (\%) & $66.09^{\mathrm{b}}$ & $68.15^{\mathrm{ab}}$ & $70.09^{\mathrm{a}}$ \\
\hline DM & $67.37^{\mathrm{b}}$ & $70.48^{\mathrm{a}}$ & $71.33^{\mathrm{a}}$ \\
\hline OM & $55.58^{\mathrm{b}}$ & $58.77^{\mathrm{ab}}$ & $63.15^{\mathrm{a}}$ \\
\hline CP & $69.49^{\mathrm{b}}$ & $73.34^{\mathrm{a}}$ & $75.08^{\mathrm{a}}$ \\
\hline EE & $60.85^{\mathrm{a}}$ & $50.61^{\mathrm{b}}$ & $48.66^{\mathrm{b}}$ \\
\hline CF & $66.43^{\mathrm{b}}$ & $69.37^{\mathrm{ab}}$ & $72.87^{\mathrm{a}}$ \\
\hline NFE & & & \\
\hline Nutritive values (\%) & $61.35^{\mathrm{b}}$ & $66.84^{\mathrm{ab}}$ & $72.07^{\mathrm{a}}$ \\
\hline TDN & 2.70 & 2.94 & 3.17 \\
\hline Digestible energy, ${ }^{*} \mathrm{DE}(\mathrm{Mcal} / \mathrm{kg})$ & 2.18 & 2.38 & 2.57 \\
\hline Metabolizable energy, ${ }^{\mathrm{b}} \mathrm{ME}(\mathrm{Mcal} / \mathrm{kg})$ & $8.87^{\mathrm{b}}$ & $9.32^{\mathrm{ab}}$ & $9.96^{\mathrm{a}}$ \\
\hline DCP & &
\end{tabular}

$a$ and b: Means in the same row followed by different superscripts are significantly different $(P<0.05)$.

${ }^{*} D E$ and ME values were calculated according to Church (1984). 
The TDN increased by increasing protected fat level. The TDN values recorded $61.35,66.84$ and $72.07 \%$ for $A, B$ and $C$ rations, respectively. Corresponding values of DE were $2.70,2.94$ and $3.17 \mathrm{Mcal} / \mathrm{kg}$ versus 2.18 , 2.38 and $2.57 \mathrm{Mcal} / \mathrm{kg}$ as ME for rations $\mathrm{A}, \mathrm{B}$ and $\mathrm{C}$, respectively, while DCP contents were $8.87,9.32$ and $9.96 \%$, respectively. Data presented in table (3) showed that including $8 \%$ protected fat in the experimental ration $(C)$ tended to be significantly $(P<0.05)$ higher in nutritive values as TDN and DCP, but inclusion $4 \%$ protected fat (ration B) insignificantly increased nutritive value (Table 3). These results were in agreement with those obtained by Zeedan et al. (2010), who found significant $(P<0.05)$ increase in digestibility coefficient of DM, OM, EE and NFE with dietary supplementation of dry fat at levels of 3 and $5 \%$ to Goats as compared to the control ration. Also, Zeedan (2003) found that protected fat in the form of Ca-soap in buffalo calves rations increased digestibility of DM, OM, CP, EE, NFE and CF than control ration. Zeedan et al. (2010) found that dry fat supplementation (3 and 5\%) in goat ration significantly $(P<0.05)$ improved the nutritive values as TDN but it had no significant effect on DCP. Palmquist and Jenkins (1980) stated that feeding unprotected fats, especially if it were unsaturated, resulted in lower ruminal fiber degradability. Pantoja et al. (1994) showed a linear reduction in ruminal NDF digestion with increasing degree of fat saturation (51.4\% for saturated tallow to $43.8 \%$ for animal-vegetable fat). Etman (1985) reported that increasing the dietary energy improved the digestibility of all nutrients except CF digestibility with male buffalo calves. Lewis et al. (1999) incubated TMR containing $5 \%$ tallow in the rumen of non-lactating Holstein cows. They observed that DM and NDF degradability decreased after $48 \mathrm{~h}$ of ruminal incubation relative to TMR containing $0 \%$ tallow.

\section{Rumen parameters:}

Data presented in table (4) illustrated that $\mathrm{pH}$ values were not affected significantly by treatment during different times of post feeding. These results are in agreement with Zeedan et al. (2010), who found that $\mathrm{pH}$ values were not affected significantly by different levels of dry fat ( 3 and $5 \%$ dry fat in goat rations. Omar. (1999) reported insignificant differences of ruminal $\mathrm{pH}$ due to fat addition. In buffalo heifers, Shahin et al. (2006) found that the ruminal $\mathrm{pH}$ (before feeding) was higher $(P<0.05)$ in low dietary energy level $(80 \%$ TDN) than high dietary energy level (120\% TDN) and the control heifers (100\% TDN). However, the ruminal $\mathrm{pH}$ did not differ significantly from the experimental rations after 3 and 6 hrs post feeding. However, Onetti et al. (2001) found that ruminal $\mathrm{pH}$ was not affected by supplemental fat (tallow $0,2,4 \%$ ) for dairy cows.

The results obtained in Table (4) revealed that the ammonia $-\mathrm{N}$ increased with increasing protected fat at different times, being the highest for ration $\mathrm{C}$, followed by ration $\mathrm{B}$ and the lowest for ration $\mathrm{A}$. However, the ammonia $-N$ concentration was significantly $(P<0.05)$ higher for ration $B$ and $C$ than that for ration $A$ at 0 and $3 \mathrm{~h}$, but at $6 \mathrm{~h}$, there were no significant differences among groups. Haddad and Husein (2004) found that ammonia-N concentration increased with inclusion of protected fat in rations. Also, Cecava et al. (1990 and 1991) found that the ruminal ammonia-N 
concentration was higher $(\mathrm{P}<0.05)$ with high dietary energy level than low dietary energy level in steers ration. However, Onetti et al. (2001) found that $\mathrm{NH} 3-\mathrm{N}$ in the rumen significantly decreased when fat was added to the diets (2 and $4 \%$ ).

In addition, the concentration of total VFAs' showed the same previous trend .Significantly $(P<0.05)$ increased with animals fed (ration $B$ and C), during different times, were shown in Table (4), while the differences in total VFAs' concentration between animal fed ration $\mathrm{B}$ (containing 4\%protected fat ) and $\mathrm{C}$ (containing $8 \%$ protected fat ) were not significant. Similarly, Haddad and Husein (2004) found that concentration of VFAs increased by inclusion protected fat in rations. Also, Shahin et al. (2006) found that the ruminal VFA concentration was higher $(P<0.05)$ in high dietary energy level (120\% TDN) than those fed low dietary energy level (80 $\%$ TDN) and the control heifers (100\% TDN) at 0,3 and $6 \mathrm{~h}$ post-feeding. However, Onetti et al., (2001) found that total volatile fatty acids concentration was not affected by supplemental fat. (tallow 0, 2 and 4\%) for dairy cows.

Table (4): Average of ruminal $\mathrm{pH}$ value, and concentration of NH3-N and total volatile fatty acids (TVFAs) in rumen liquor of lambs fed the experimental rations.

\begin{tabular}{|l|c|c|c|c|}
\hline \multirow{2}{*}{ Item } & Time & \multicolumn{3}{|c|}{ Experimental ration } \\
\cline { 2 - 5 } & $(\mathbf{h})$ & $\mathbf{A}$ & $\mathbf{B}$ & $\mathbf{C}$ \\
\hline \multirow{3}{*}{$\mathrm{pH}$ value } & 0 & 6.87 & 7.00 & 7.03 \\
\cline { 2 - 5 } & 3 & 5.37 & 5.27 & 5.83 \\
\cline { 2 - 5 } & 6 & 5.90 & 5.57 & 6.10 \\
\hline \multirow{3}{*}{ Ammonia-N (mg/100ml RL) } & 0 & $25.20^{\mathrm{b}}$ & $26.70^{\mathrm{a}}$ & $27.27^{\mathrm{a}}$ \\
\cline { 2 - 5 } & 3 & $26.67^{\mathrm{b}}$ & $29.00^{\mathrm{a}}$ & $29.57^{\mathrm{a}}$ \\
\cline { 2 - 5 } & 6 & 24.50 & 24.60 & 25.07 \\
\hline \multirow{3}{*}{ TVFA's (meq/100 ml RL) } & 0 & $12.40^{\mathrm{b}}$ & $14.20^{\mathrm{a}}$ & $15.27^{\mathrm{a}}$ \\
\cline { 2 - 5 } & 3 & $13.73^{\mathrm{b}}$ & $17.20^{\mathrm{a}}$ & $18.11^{\mathrm{a}}$ \\
\cline { 2 - 5 } & 6 & $12.97^{\mathrm{b}}$ & $14.73^{\mathrm{a}}$ & $14.87^{\mathrm{a}}$ \\
\hline \multirow{2}{*}{ a, b and c: means in the same row followed by different superscripts are significantly }
\end{tabular}
different $(P<0.05)$.

\section{Blood parameters:}

Data presented in table (5) illustrated that the differences in concentration of albumin, globulin and cholesterol were not significant $(P<0.05)$ among different experimental rations, but differences in total proteins concentration were significant $(P<0.05)$ between animal fed ration $A$ and C. Also, concentration of total lipids and triglycerides was significantly $(P<0.05)$ the highest for animals fed ration $C$, followed by ration $B$ and the lowest in those fed the control ration (ration A). . Activity of AST and ALT was significantly $(P<0.05)$ higher with protected fat rations. Generally, all blood parameters illustrated in table (5) were higher with adding $4 \%$ protected fat to experimental rations than the control, but adding $8 \%$ protected fat yielded the highest values. These results are in agreement with those obtained by Zeedan et al.,(2010), who found that concentration of plasma total proteins, albumin, glucose, total cholesterol, triglycerides and total lipids was 
significantly higher $(P<0.05)$ with adding different levels dry fat $(3$ or $5 \%)$ for goat rations. However, Sallam et al. (2005) found that the plasma concentration of cholesterol significantly decreased with energy level $120 \%$ of goat rations.

Table (5): Effect of different levels of energy on some blood parameters of experimental rations.

\begin{tabular}{|l|c|c|c|}
\hline \multirow{2}{*}{ ttem } & & Experimental & rations \\
\cline { 2 - 4 } & A & B & C \\
\hline Total protein (g/dl) & $9.83^{\mathrm{b}}$ & $10.70^{\mathrm{ab}}$ & $10.90^{\mathrm{a}}$ \\
\hline Albumin (g/dl) & 6.50 & 6.07 & 6.70 \\
\hline Globulin $(\mathrm{g} / \mathrm{dl})$ & 3.33 & 4.63 & 4.20 \\
\hline AST (RFU/ ml) & $18.67^{\mathrm{c}}$ & $25.67^{\mathrm{b}}$ & $34.67^{\mathrm{a}}$ \\
\hline ALT (RFU/ ml) & $16.00^{\mathrm{c}}$ & $20.33^{\mathrm{b}}$ & $27.00^{\mathrm{a}}$ \\
\hline Total lipids (g/dl) & $442.3^{\mathrm{c}}$ & $452.3^{\mathrm{b}}$ & $480.0^{\mathrm{a}}$ \\
\hline Triglycerides (mg/dl) & $75.87^{\mathrm{c}}$ & $85.87^{\mathrm{b}}$ & $96.00^{\mathrm{a}}$ \\
\hline Cholesterol $(\mathrm{mg} / \mathrm{dl})$ & 97.33 & 103.00 & 103.67 \\
\hline
\end{tabular}

a and b: means in the same row followed by different superscripts are significantly different( $P<0.05)$.

\section{Growth performance:}

The data obtained in table (6) showed that the total and daily weight gain increased by inclusion of protected fat in animal rations. Average total weight gain was $27.04,29.30$ and $31.63 \mathrm{~kg}$ for animals fed rations $A, B$ and C, respectively. The corresponding average daily gain was 241,262 and 282 g, respectively.

Feed intake as DM, TDN and DCP/ head are shown in table (6). The highest intake of DM was recorded with animal fed ration $A$, followed by those fed ration $C$ and $B$. However, TDN and DCP intakes showed the highest values with animals fed ration $C$, followed by those fed rations $A$ and $B$. It could be noticed an improvement in feed conversion as $\mathrm{kg} D M, \mathrm{~kg}$ TDN and $\mathrm{kg} \mathrm{DCP} / \mathrm{kg}$ gain of animal fed rations containing protected fat than the control. The best feed efficiency as $\mathrm{kg} D M$ required for $\mathrm{kg}$ gain was obtained with animals fed ration $\mathrm{C}$, being $4.550 \mathrm{~kg}$, while animals fed ration $\mathrm{B}$ showed the best TDN and DCP efficiency (3.172 $\mathrm{kg}$ TDN and $0.443 \mathrm{~kg} \mathrm{DCP} / \mathrm{kg}$ gain, respectively). The present results are in agreement with those obtained by McCartor and Smith (1978), who found that final body weight was not different for steers fed supplemental protected tallow as compared with a basal diet. Al Jassim et al. (1996) observed that weight gain was highly correlated with ME intake. Zinn (1989a) observed a linear improvement in body weight gain for steers given 4 and $8 \%$ of either yellow grease or blended animal-vegetable fat. However, Haddad and Younis (2004) found no difference in weight gain of Awassi lambs fed 2.5 and $5 \%$ fat. Shahin (2004) reported that the average daily gain was significantly higher for $120 \%$ TDN group than those fed 100 or $80 \%$ TDN. Also, Khinizy et al. (2004) found higher weight gain of lambs fed high energy diets (66\% TDN) than those fed low energy diet (55\% TDN). Ebrahimi et al. (2007) reported that the average daily gain were higher $(P<0.05)$ in high dietary energy level by 49.53 and $24.16 \%$ than low dietary energy level and the control rams, respectively. 
Sheridan et al (2003) found that the feed conversion of Boer goats and Mutton Merino rams was higher $(P<0.05)$ in high dietary energy level than those fed low dietary energy levels $(7.65$ vs. 6.37 and 8.73 vs. $5.56 \mathrm{~kg}$ feed/BW gain), respectively. Moreover, Ebrahimi et al. (2007) reported that the feed conversion ratio in rams was improved $(P<0.05)$ with increasing dietary energy levels.

Table (6): Average daily feed intake, daily gain and feed efficiency of animals fed the experimental rations.

\begin{tabular}{|l|c|c|c|}
\hline \multirow{2}{*}{ Item } & \multicolumn{3}{|c|}{ Experimental ration } \\
\cline { 2 - 4 } & A & B & C \\
\hline Number of animals & 8 & 8 & 8 \\
\hline Feeding period (/day) & 112 & 112 & 112 \\
\hline Initial body weight, $\mathrm{kg}$ & 31.83 & 33.67 & 31.67 \\
\hline Final body weight, $\mathrm{kg}$ & 58.87 & 62.97 & 63.30 \\
\hline Total gain, kg & $27.04^{\mathrm{b}}$ & $29.30^{\mathrm{b}}$ & $31.63^{\mathrm{a}}$ \\
\hline Average daily gain, g/head/day & $241^{\mathrm{c}}$ & $262^{\mathrm{b}}$ & $282^{\mathrm{a}}$ \\
\hline Improvement (\%) & - & 8.71 & 17.01 \\
\hline Average daily feed intake(as DM): \\
\hline Total DM intake, kg/head/day & 1.400 & 1.243 & 1.283 \\
\hline Total TDN, kg/head/day & 0.859 & 0.831 & 0.925 \\
\hline Total DCP, kg/head/day & 0.124 & 0.116 & 0.128 \\
\hline Feed efficiency: & 5.809 & 4.744 & 4.550 \\
\hline Kg DM/kg,gain & 3.564 & 3.172 & 3.280 \\
\hline Kg TDN/kg,gain & 0.515 & 0.443 & 0.454 \\
\hline Kg DCP/kg,gain \\
\hline a, b and c: means in the same row followed by different superscripts are significantly
\end{tabular}

a, $b$ and c: means in the same row followed by different superscripts are significantly different $(\mathrm{P}<0.05)$.

\section{Feed cost and economical efficiency :}

Data presented in table ( 7 ) showed that the cost of feed intake decreased with using protected fat as a source of energy. Feed cost per kg weight gain gradually decreased with decreasing amount of yellow corn and increasing protected fat in formulated rations, being 16.041, 12.500 and 12.060 LE for rations $\mathrm{A}, \mathrm{B}$ and $\mathrm{C}$, respectively. At the same time, the revenue value increased with decreasing feed cost, being $3.364,4.585$ and 5.059 LE for the previous respective rations, showing the best revenue with ration $\mathrm{C}$. Also, animals fed ration $\mathrm{C}$ showed the highest margin above feed cost (1.488 LE). Accordingly, economic efficiency was 1.870, 2.400 and $2.488 \%$,respectively. Moreover, the improvement of economical efficiency was 28.34 and $33.05 \%$ for animals fed rations B and C, respectively. 
Table (7): Average daily feed intake, daily gain, feed cost and economical efficiency.

\begin{tabular}{|l|c|c|c|}
\hline \multirow{2}{*}{ Item } & \multicolumn{3}{|c|}{ Experimental ration } \\
\cline { 2 - 4 } & $\mathbf{A}$ & $\mathbf{B}$ & $\mathbf{C}$ \\
\hline Average daily feed intake, (as fed) $\mathrm{kg}$ & 1.582 & 1.393 & 1.432 \\
\hline Average daily gain, kg & 0.241 & 0.262 & 0.282 \\
\hline${ }^{\star}$ Cost of feed intake (LE) & 3.866 & 3.275 & 3.401 \\
\hline Price of weight gain (LE) & 7.230 & 7.860 & 8.460 \\
\hline Feed cost /kg weight gain (LE) & 16.041 & 12.500 & 12.060 \\
\hline Revenue ( LE/head /day ) & 3.364 & 4.585 & 5.059 \\
\hline Gross margin above feed cost (LE) & 0.870 & 1.400 & 1.488 \\
\hline Economical efficiency (\%) & 1.870 & 2.400 & 2.488 \\
\hline Improvement of economical efficiency (\%) & 0 & 28.34 & 33.05 \\
\hline
\end{tabular}

* Based on the assumption that the prices of one ton of complete ration without or with protected fat was 2450,2339 and 2355 LE for rations A,B and C, respectively, and the price of one $\mathrm{kg}$ live body weight in selling was $30 \mathrm{LE}$.

\section{CONCLUSION}

From these results, it could be concluded that using protected fat instead of a part of yellow corn as a source of energy tended to improve digestibility of most nutrients and nutritive values as TDN and DCP, with normal rumen function and blood plasma parameters. Increasing level of protected fat up to $8 \%$ in experimental ration have to give the highest daily gain with the best feed efficiency and the highest economic feed efficiency.

\section{REFERENCES}

Al Jassim, R.A.M.; S. A. Hassan and A. N. Al-Ani (1996). Metabolizable energy requirements for maintenance and growth of Awassi lambs. Small Ruminant Res. 20, 239-245.

A.O.A.C. (2000). Official Methods of Analysis, Association of Official Analytical Chemists. Washington, D.C., USA.

Cecava, M. J.; N. R .Merchen,.; L. L. Berger; R. L. Mackie and G. C. Jr. Fahey (1991). Effects of dietary energy level and protein source on nutrient digestion and ruminal nitrogen metabolism in steers. J. Anim. Sci. 69:223-2243.

Cecava, M. J.; N. R. Merchen.; L.L. Berger and D. R. Nelson (1990). Effect of energy level and feeding frequency on site of digestion and postruminal nutrient flows in steers. J Dairy Sci. 73:247-2479.

Chilliard, Y. (1993). Dietary fat and adipose tissue metabolism in ruminants, pigs, and rodents: a review. J. Dairy Sci. 76, 3897-3931.

Church, D.C. (1984) Livestock feeds and feeding , $2^{\text {nd }}$ Ed. OKB books, Inc., Corvallis, Oregon, USA.

Devendra, C. and D. Lewis (1974). Fat in the ruminant diet: review. Ind. J. Anim. Sci. 44, 917-938.

Doreau, M. and Y. Chilliard, (1997). Digestion and metabolism of dietary fat in farm animals. Br. J. Nutr. 78, S15-S35. 
Drupt, E. (1974) . Colorimetric determination of albumin. Biol. J. 9:777.

Duncan, D.B.(1955). Multiple range and multiple F. test . Biometricies, 11:142.

Eadie,J.M.; P.N. Hpbson and S.O.Mann (1967). A note on some comparisons between the rumen content of barley fed steers and that of young calves fed on high concentrate rations. J. Anim. Prod. 9:247.

Ebrahimi, R.; H. R. Ahmadi; M. J. Zamiri and E. Rowghani (2007). Effect of energy and protein levels on feedlot performance and carcass characteristics of Mehraban ram lambs. Pakistan J. Bio. Sci. 10 (10): 1679-1684.

Etman, K. E. I. (1985). The effect of level concentrate feeding and roughage on meat production. Ph. D. Dissertation, Fac. Agric., Zagazig Univ.

Haddad, S. G. and M.Q. Husein (2004). Effect of energy density on growth performance and slaughtering characteristics of fattening Awassi lambs. Livestock Production Science 87. 171-177.

Haddad, S. G. and H. M. Younis (2004). The effect of adding ruminally protected fat in fatting diets on nutrients intake, digestibility and growth performance of Awassi lambs. Animal Feed Science and Technology, 113:61-69.

Jenkins, T.C. and B.F. Jenny (1989). Effect of hydrogenated fat on feed intake, nutrient digestion, and lactation performance of dairy cows. J. Dairy Sci., 72, 2316-2323.

Khinizy, A. E.; I. M. M. Saddiek; A. A. B. Ahmed and F. H. Shahin (2004). Effect of energy level and protein source on sheep performance. 1Performance of weaned lambs. Egypt. J. Nutr. and Feeds., 7 (1): 5567.

Lewis, W. D.; J. A. Bertrand and T. C. Jenkins (1999). Interaction of tallow and hay particle size on ruminal parameters. J. Dairy Sci., 82:15321537.

McCartor, M.M. and G.C. Smith (1978). Effect of protected lipids on feedlot performance and carcass characteristics of short-fed steers. J. Anim. Sci., 47, 270-275.

Nigdi, M.E.; S.C. Loerch; F.L. Fluharly and D.L. Palmquist (1990). Effects of calcium soaps of long-chain fatty acids on feedlot performance, carcass characteristics and ruminal metabolism of steers. J. Anim. Sci., 68, 2555-2565.

NRC, (1985) Nutrient Requirements of Sheep .6th ed. Acad. Sci., Washington, DC.

Omer, F. M. A. (1999). Using protected fat prepared from soap industry by products in inishing rations of Friesian .Ph.D. Thesis Faculty of Agriculture, Cairo University.

Onetti, S. G. ; R. D. Shaver; M. A. McGuire and R. R. Grummer (2001). Effect of type and Level of dietary fat on rumen fermentation and performance of dairy cows fed corn silage-based diets .J. Dairy Sci., 84:2751-2759.

Palmquist, D. L. and T. C. Jenkins (1980). Fat in lactation rations: Review. J. Dairy Sci., 63:1-14. 
Pantoja, J.; J. L. Firkins; M. L. Eastridge and B. L. Hull (1994). Effects of fat saturation and source of fiber on site of nutrient digestion and milk production by lactating dairy cows. J. Dairy Sci. 77:2341-2356.

Reitman, S. and S. Frankel (1957). Calorimetric determination of AST and ALT activity. Am. J. Clin. Path., 28, 56-63.

Sallam, S. M. A.; M. E. A. Nasser and M. I. Yousef (2005). Effect of recombinant bovine somatotropin administration on milk production, composition and some hemato-Biochemical parameters of lactating goats. Small Ruminant Research 56, 165-171.

SAS (1985). SAS / STAT user's Guide: statistics. $4^{\text {th }}$ Ed., SAS institute Inc., Cary, NC.

Scheletter, G. and E. Nussel (1975). Arbeitsmed Sozialmed Pracentimed. 10:25.

Shahin, G. F. (2004). Effect of dietary energy level on: 1- Digestibility and performance of growing buffalo heifers. Egyptian J. Nutrition and Feeds 7 (1): 43-53.

Shahin, G. F.; A. A. Zaki and H. EL-Matarawy (2006). Effect of dietary energy level on nutrient utilization, rumen fermentation, productive and some reproductive performances of pregnant buffalo heifers. Egypt. J. Nutr. and Feeds 9 (2): 159-177.

Sheridan, R.; A. V. Ferreira and L. C. Hoffman (2003). Production efficiency of South African Mutton Merino lambs and Boer goat kids receiving either a low or a high energy feedlot diet. Small Ruminant Research, 50: $75-82$.

Stein, EA. (1986). In Textbook of Clinical Chemistry, NW Tietz, ed. W.B. Saunders, Philadelphia, pp.879-886. USA.

Sutton, J.D.; R. Knigh; A.B McAllan; R.H. Smith( 1983). Digestion and synthesis in the rumen of sheep given diets supplemented with free and protected oils.

J. Anim. Sci., 49, 419-432.

Weichselboum, F.(1946). Colorimetric determined of total protein. An. J. Clin. Path. 16.40.

Zeedan, Kh. I. I.; O. F. Komonna; K. E. IEtman, and Kh. M. M. Mousa (2010). Using different levels and sources of fats and roughages in feeding Goats 1-Effect on productive and reproductive performance .Egyptian and feeds .13(1):61-80.

Zeedan, Kh. I. I. (2003). Effect of dietary fat on performance ,rumen fermentation and some blood parameters on buffalo. Ph. D. Thesis Anim. Prod. Dept. Menoufia.

Zinn, R.A. (1989a). Influence of level and source of dietary fat on its comparative feeding value in finishing diets for steers: feedlot cattle growth and performance. J. Anim. Sci., 67, 1029-1037. 


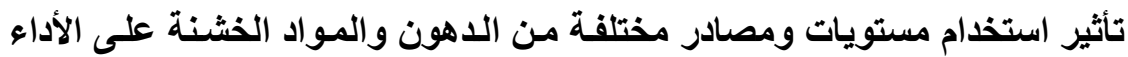

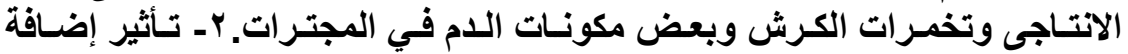

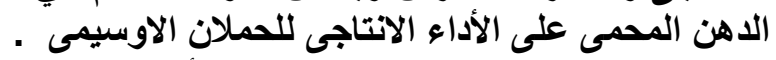

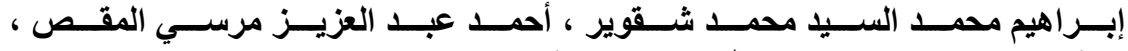

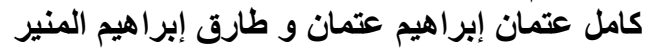

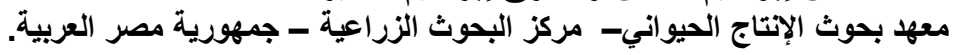

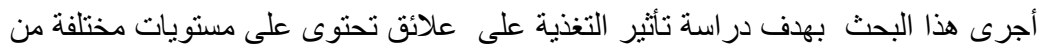

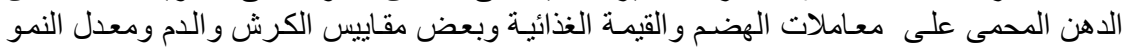

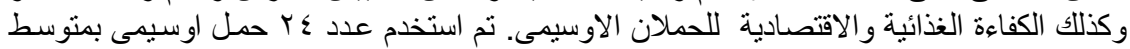

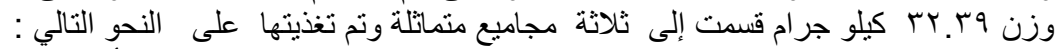

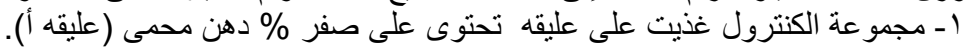

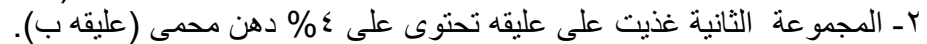

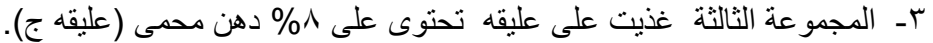

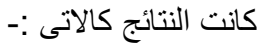

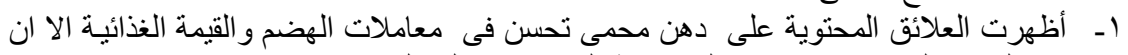

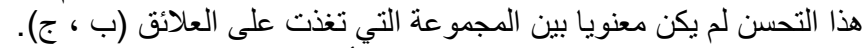

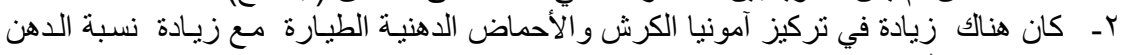

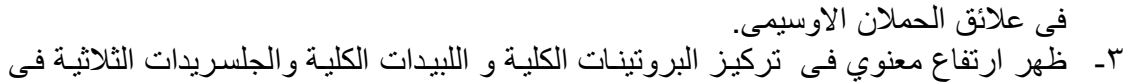

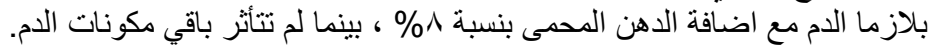

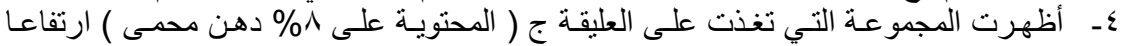

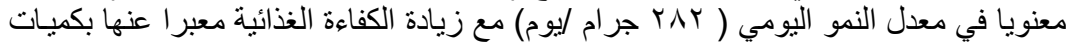

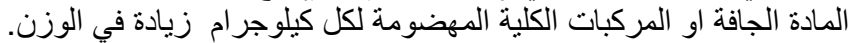

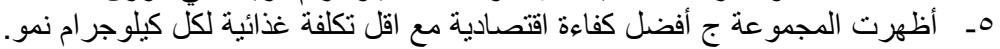

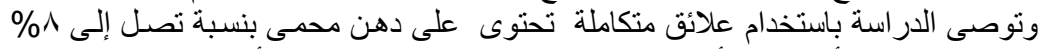

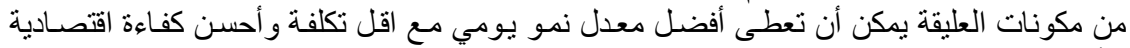

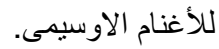

